\title{
Field theory, media change and the new citizen movements: Spain's «real democracy» turn as a series of fields and spaces
}

\author{
La teoría de los campos, el cambio mediático y los nuevos \\ movimientos ciudadanos: el giro hacia la "democracia real» \\ en España como una serie de campos y espacios
}

JOHN POSTILL

Rmit University-Melbourne (Australia)

Artículo recibido: 13 marzo 2017

Artículo aceptado: 22 abril 2017

\begin{abstract}
A post-Bourdieu version of field theory can produce nuanced analyses of the relationship between media change, the new citizen movements and ongoing struggles for democratic renewal. Through the case of Spain's indignados $(15 \mathrm{M})$ movement and its political offshoots, I explore the potential uses of a range of field concepts and propose a conceptual distinction between «field of civic action» and «dispersed civic space». Spain's recent political changes are not a continuous flow of events but rather a series of discrete, ephemeral fields of civic action separated by a long hiatus of dispersed civic space. These complexly mediated fields are socio-political «games» in which civic players with technopolitical and other skills interact with other players in pursuit of specific goals and rewards. As a result, new citizen-led initiatives (e.g. PAH, Podemos, Barcelona en Comú) have bridged the alternative vs. mainstream media divide to great social and political effect.
\end{abstract}

Keywords: Field theory, citizenship, protest movements, media, democracy, 15M, indignados, Podemos, Barcelona en Comú, Spain

Resumen

Una versión de la teoría de campos post-Bourdieu puede producir análisis matizados de la relación entre el cambio de los medios de comunicación, los nuevos movimientos ciudadanos y las luchas por la renovación democrática actuales. Partiendo del movimiento de los indignados en España (15M), exploro los usos potenciales de una serie de conceptos de campo y propongo una distinción conceptual entre «campo de acción cívica» y «espacio cívico disperso». Los recientes cambios políticos en España no son un flujo continuo de acontecimientos, sino una serie de campos discretos y efímeros de acción cívica separados por un largo período de dispersión del espacio cívico. Estos campos complejamente me- 
diados son «juegos» sociopolíticos en los que actores cívicos con habilidades tecno-políticas y de otra índole interactúan con otros jugadores en busca de metas y recompensas específicas. Como resultado, las nuevas iniciativas dirigidas por los ciudadanos (por ejemplo, $\mathrm{PAH}$, Podemos o Barcelona en Comú) han sido capaces de salvar las distancias entre los medios de comunicación alternativos y los principales medios de comunicación de masas y han tenido un gran efecto social y político.

Palabras clave: teoría de campos, ciudadanía, movimientos de protesta, medios de comunicación, democracia, 15M, indignados, Podemos, Barcelona en Comú, España

\section{INTRODUCTION}

The end of the Franco regime (1939-1975) ushered in a period of democratisation but also a protracted crisis of citizenship in Spain. Writing thirty years after the dictator's death, the sociologist Jorge Benedicto (2006) argued that civic rights took precedence over social rights in Spain both during the transition years and beyond. At a time of economic crisis, when northern Europe's post-War «redistributive revolution» had already come to an end (Rosanvallon, 2013), democratic Spain's efforts to create a welfare state were subordinated to the macroeconomic demands of global competition and a neoliberal ideology (Benedicto, 2006: 112).

Out of Franco's military regime emerged a «transition culture» (cultura de la transición) whose institutional foundations were laid in October 1977 at the Moncloa Pact - an agreement signed by leading formations across the political spectrum (from Communists to ex-Francoists) and by the major trade unions. The emphasis was on national unity, political stability and social cohesion. To be allowed into this new order, Spain's left agreed to «deactivate» its two key assets: culture and social mobilisation. In exchange, the state rewarded the leftist cultural sector with lavish funding and awards. It also promised to save Spain from the army, the church and Basque terrorism (VV.AA., 2012).

Although officially encouraged to exercise their democratic rights by the regime's political elites, Spanish citizens were in practice assigned the role of passive audiences in the new, televised political spectacle. Benedicto (2006: 128) describes this situation as «a chronic deficit of civic practices». Writing in the mid-2000s, this author did, however, glimpse a ray of hope in Spaniards' penchant for protesting - second only to Luxembourg in Europe: 
[Spain's] model of citizenship is not entirely clear, as a high degree of institutionalisation of civic rights contrasts sharply with a scarcity of civic practices, although there are interesting signs that this situation may be changing (Benedicto, 2006: 128, my translation).

These were prescient words, for five years later, in May 2011, unprecedented numbers of Spaniards took to the streets and squares - as well as to the internet - to demand "real democracy now», giving birth to a new citizen movement known today as $15 \mathrm{M}$ or indignados. In turn, the new movement brought about an explosive growth and diversification of civic practices, ranging from «monitory democracy» (Feenstra and Keane, 2014; Keane, 2009) practices seeking to bring corrupt politicians and financiers to justice to new citizen parties contesting European, local and national elections.

In this article I explore the impact of these new developments on the reconceptualization and practice of citizenship in Spain at a time of rapid technological change. I ask to what extent the $15 \mathrm{M}$ movement, including its political offshoots, has contributed to the emergence of a new language and praxis of citizenship in Spain. If so, with what political consequences?

Below I propose an advanced version of field theory as a highly promising approach to make headway in this area, debunking the common misperception that field theory is unsuited to the study of change. My argument is that $15 \mathrm{M}$ has indeed transformed the language and practice of citizenship in Spain, yet it has done so in stages. From an earlier movement phase (or field "game») in which «the citizenry» (la ciudadanía) was conceived of, and mobilised, as an extra-institutional formation demanding «real democracy now» through a middle phase of «monitory citizenship» we eventually arrived, in 2014-2015, at a phase where new citizen parties entered the electoral arena determined to take power, and succeeding in major cities such as Madrid and Barcelona. In doing so, they gave a new twist to the ongoing reinvention of citizenship in Spain by breaking with the country's autonomous tradition of extra-institutional civic action.

\section{CITIZENSHIP, ICTS AND SOCIAL MOVEMENTS}

We still know surprisingly little about the links between citizenship, ICTs and social movements. For Papa and Milioni (2013), the relationship between social movements and citizenship is dialectical: civic identities «not only serve as a precondition or a drive for participating in social 
movements, but are also conducted or transformed by this activity» (2013: 28). These authors call for non-technocentric research into the novel forms of citizenship, if any, that are being constructed within the new movements, and the role played by ICTs in such processes.

This contrasts with the approach taken by Constanza-Chock (2012) who argues that we must look at the whole media repertoire of the new movements, and not merely at ICTs or social media. Although sympathetic to this latter stance, I would go one step further and suggest the need to expand our holism from the media repertory of social movements to the entire media environment. Chadwick's (2012) simple but powerful notion of «hybrid media systems» is apposite. This is the idea that new media systems are a combination of old and new media technologies, practices and actors interacting in complex, non-teleological ways. Chadwick's concept shifts the focus from a recurrent media studies concern with «What is new about «new» media?» (Silverstone, 1999) to the holistic question of «What is new about new media systems?» His position, which I share, is that the newness of any media system - and indeed of any other social universe - is inevitably the emergent result of a combination of old and new artefacts, ideas and actors.

Thus, Spain's present-day media system, like that of all other coeval states, is a dynamic totality largely made up of twenty-first century (blogs, social media, smartphones) and earlier (radio, TV, newspapers, etc.) media technologies, producers and users. The question is not whether media environments in the 2010 s are new - they clearly are - but rather what the main continuities and changes are with regard to earlier historical periods.

\section{A FIELD-THEORETICAL APPROACH}

A revised, post-Bourdieu version field theory can be of great value to the development of more nuanced analyses of the relationship between systemic media changes and the rise of new citizen movements. Taking as my example Spain's indignados (15M) movement and its recent political offshoots, below I explore the potential uses of a range of field concepts, including two new coinages introduced here for the first time: «field of civic action» and «dispersed civic space». I argue that Spain's 15M movement is best understood not as a continuous flow of events but rather as a series of discrete, ephemeral fields of civic action separated by a long 
period of dispersed civic space. These transient, complexly mediated fields can be regarded as socio-political games of a certain kind, namely as contests in which civic "players» with unique sets of skills, including "freedom technologists» (defined below, see also Postill, 2014a), enter into relationships with other players (both individual and collective) in pursuit of common public rewards or prizes. Of particular salience in the Spanish case is the emergence of citizen-led initiatives (e.g. PAH, Podemos, Barcelona en Comú) that have learned how to bridge the civic vs. establishment media divide to great effect. These transmedia actors demonstrate the need for holistic analyses of the dynamic hybrid media systems in which today's civic initiatives operate.

A field-theoretical approach allows us to study the emergence and evolution of civic movements diachronically and in a differentiated manner, rather than assuming a single transformative event, such as the square occupations or the sudden rise of Podemos. With its reputation for emphasising social reproduction at the expense of social change (Born, 2010; Butler, 1999; Gledhill 2000), field theory may seem a strange choice to make in this context. However, this association of field theory with stasis is a misconception derived from a superficial reading of its most renowned exponent, Pierre Bourdieu $(1990,1993,1996)$. In fact, field theory is equipped to handle both continuity and change (Fligstein and McAdam, 2011, 2012; Postill 2011, 2015). It offers a rich, supple conceptual vocabulary with which to explore the elusive relationship between media change and the new citizen movements.

Having cleared this misunderstanding, let us start with two related variants of the concept of field. Fligstein and McAdam $(2011,2012)$ define strategic action fields (SAFs) as

the fundamental units of collective action in society. A strategic action field is a meso-level social order where actors (who can be individual or collective) interact with knowledge of one another under a set of common understandings about the purposes of the field, the relationships in the field (including who has power and why), and the field's rules (Fligstein and McAdam, 2011:3).

Modifying this definition, I will define field of civic action as

a game-like domain of social action entangled in a web of other domains in which differently positioned citizens and civic initiatives compete and cooperate over the same issues, goals and rewards - often via digital media. Field actors interact with knowledge of one another under a set of common understandings about the purposes of the field, the relationships in the field (including who has power and why), and the field's rules. 
The introduction of this new concept is justified on two grounds. First, it refers specifically to the topic that occupies us here, namely the new citizen movements. Second, not all actions are strategic, not even within a highly competitive field in which the stakes are high. That is to say, not all "players» will be equally invested in the illusio of the game. Some will play for the sake of playing, others by mistake, or out of obligation, boredom, or any other number of reasons. That does not mean, pace Warde (2004: 21), that the analogy of fields as games is not apt. Although fields of civic action clearly are not games like chess, tennis or Minecraft, they nonetheless resemble games. Fields are «space[s] of competition, the analogy being a game of chess where players enter the game and position themselves according to the powers and moves available to them». Yet in contrast to a game of chess with its well-defined, unchanging rules, powerful field players will also struggle over the definition of what counts as the «stakes» in the field (Prior, 2008: 305).

Fields of civic action tend to be much more mercurial, unpredictable and short-lived than the more institutionalised fields we associate with the work of Bourdieu $(1993,1996)$, e.g. the fields of art, sociology or journalism. This low institutionalisation means that field agents (both individual and collective) must work much harder at anticipating and interpreting other agents' actions, seeking and maintaining alliances, finding useful ways of exploiting the field affordances of new technologies, and so forth.

Social fields are never fully insulated from their environment. They are always part of a much larger web of fields - some proximate, others more distant; some powerful, others weak. The following observation about the shifting boundaries of strategic action fields (SAFs) applies equally well to fields of civic action:

The boundaries of SAFs are not fixed, but shift depending on the definition of the situation and the issues at stake. So, for instance, imagine if [the US] Congress were to take up a sweeping reform bill that threatened to change the tax status of all institutions of higher education. [This] conflict would define a new field, comprised of all 2,500 colleges and universities [in the United States], which would probably unite and oppose such legislation. So fields are constructed on a situational basis, as shifting collections of actors come to define new issues and concerns as salient (Fligstein and McAdam, 2011:4).

Another common feature of contemporary fields is that they have go by universal clock-and-calendar time (Postill, 2002, 2006). A crucial distinction to make in this regard is whether or not the fields of civic action being 
analysed come with an «expiry date». We shall see shortly the significance of this seemingly banal distinction in the context of Spain's indignados (15M) movement.

Individuals and groups bring to a field of civic action uneven amounts of social, technical and political capital. They also join the field at different times and places. This strongly influences - but never entirely determines - their position within the field. As a result, a broad division between «incumbents» and "challengers» always emerges (Fligstein and McAdam, 2011: 5-7). Incumbents have an obvious interest in retaining their position of strength vis-a-vis challengers, and will seek alliances with other individual and group players to achieve this end.

Fields of civic action are always on the move, steered through «internal governance units» that are distinct from external units, such as those of local or national government (Fligstein and McAdam, 2011: 6). Spanish examples would include popular assemblies, working committees, Facebook groups or Twitter accounts. These units are where we can expect to find the field's core transient practices, i.e. those essential practices that define a field at a given point in time, without which it would lose its raison d'être and cease to function (see Postill, 2015 for the changing core practices of American journalism). It is at these field «stations» where the field is routinely reproduced that we are likely to observe the field's incumbents busily holding onto their power, with varying degrees of success (Postill, 2011: 7). It is also here that the «aim and name of the game» are discussed, reinforced, contested, and sometimes modified. During periods of turbulence or crisis within a field, stations can mutate into «arenas» in which incumbents and challengers are forced to take sides on an internal dispute. Arenas are where «social dramas» pitting field actors against each other are played out in public view (Turner, 1974: 132-133) - nowadays usually via digital/viral media platforms (Postill, 2011: 8).

Contingent on the specific dynamics of a situation, field agents will sometimes clash and sometimes cooperate with other agents over the same issues, goals and rewards, with conflict usually gaining the upper hand. As the anthropologist Victor Turner perceptively put it forty years ago, political fields are constituted by «purposive, goal-directed group action, and though it contains both conflict and coalition, collaborative action is often made to serve the purposes of contentious action» (1974: 128). Whereas some rewards will be intrinsic to the field, others are extrinsic (Warde, 2005), e.g. prizes or recognition awarded by the state or the private sector. Some fields of civic action will be constituted around a sin- 
gle issue (see the US higher education example above), whereas in others a set of issues will compete for players' attention and dedication.

It follows that the larger the number of issues at stake, the greater the risk of field fragmentation and dispersal. When a field of civic action ceases to operate effectively, i.e. when there is no single shared game being played, and there are no internal governance units, no central stations, and so on, the field reverts to a state of fallow. After this period, the field may or may not regenerate itself through a new shared game.To adapt Fligstein and McAdam's (2011) notion of «unorganised social space» to the case of citizen movements, I shall refer to this state as «dispersed civic space».

Like all other societal fields, fields of civic action are embedded in hybrid media systems (as defined above, see Chadwick, 2013) that are largely not of their own making. However, tech-minded players will still strive to develop practices that will allow them to win hearts and minds under these new media conditions, in the process gradually changing the very infrastructures on which civic publics are sustained (Kelty, 2008). Here we can distinguish between "civic media practices» (i.e. those practices that take place largely or entirely within «circuits of civic culture», Dahlgren, 2009; Couldry et al, 2014) and «hybrid media practices» (those that straddle the establishment vs. civic media divide). For example, regularly organising protests through digital mapping, Facebook announcements and other techniques is a civic media practice (see Boler et al, 2014). By contrast, joining civic and non-civic actors (e.g. journalists, politicians, celebrities) via Twitter hashtags to comment on live TV broadcasts is clearly a hybrid media practice located directly on an unstable political and discursive fault line.

\section{THE 15M FIELD OF CIVIC ACTION: «MARCH THE STREETS!»}

How does this extended family of field and media concepts help us understand Spain's 15M (indignados) movement? Is this protest movement a field of civic action? The answer to these questions is surprising: rather than a single «movement-field» (Juris, 2008; Postill, 2015), 15M is better understood as a series of distinct fields separated by a long period of dispersed civic space.

Let us start with the 15 May 2011 marches, before briefly considering later phases of the movement. The 15 May demonstrations around Spain were not the result of a single «exogenous shock» (Fligstein and McAdam, 
2011: 8-9) to Spain's civil society but rather of several domestic and international shocks, most notably the collapse of the Spanish economy in the wake of the global financial crisis of 2008 (Perugorría and Tejerina, 2013: 428) and the Euro crisis (Bourne and Chatzopoulou, 2015; Dekker and Feenstra, 2015).

To understand the marches from a field-theoretical perspective we must ask questions about the making of this new field/game, about its individual and group players, about its implicit and explicit «rules» and who got to write them, about its expiry date (if any), its freedom technologists, and so on.

First, we should consider the aim and name of the game. Here we must be aware of an old anthropological problem with folk (or emic) categories. Whilst these can sometimes be illuminating, at times they can also be obfuscating. For example, if we took popular 15M slogans such as «Real democracy now!» or "Take the street!» (joma la calle!) at face value, we would be missing out on what the game was actually about, namely getting as many citizens as possible to peacefully march the streets of Spain on 15 May 2011 and then go bome. The aim of the game was not to «take» or to «occupy» the streets - or indeed, any other public space. Occupying Madrid's main square, Puerta del Sol, was never part of the game. «Take the street!» is therefore a misnomer. A more fitting slogan for this game, admittedly a less compelling one, would be: «March the streets!».

One fundamental component of the «March the streets!» game, yet one easily overlooked given how fully naturalised clock-and-calendar time has become (Postill, 2002), is that it came with a firm, undisputed expiry date. Indeed the very name of the game was the date of both its doing and undoing: $15 \mathrm{M}$ ! Beyond that date, it was game over. Contrary to much of the visual imagery about Spain's «indignados», this was no spontaneous wave of youthful protest, but rather a carefully choreographed public performance of outrage (Gerbaudo, 2012) that followed months of intense preparation by activists and others from a wide age range (in my experience, most people actively involved in the preparations were aged from 20 to 50).

Even though its members made sophisticated use of a rich suite of digital technologies, Real Democracy Now! (DRY) was more than merely a "digital platform», as described in the quote above. DRY was physically headquartered in venues long associated with Spain's thriving free culture movement, such as Patio Maravillas in Madrid and Conservas in Barcelona (Postill, 2014a). Free culture activists struggle to liberate digital culture from the tight grip of large governments and corporations. These brick- 
and-mortar sites (along with online sites such as Facebook, Twitter, n-1, etc.) were the stations where the game was rehearsed in the months and weeks prior to the big day - places of planning, organising and training. They were also the field's internal governance units. It was here that a broad coalition of civic platforms formed by DRY, Juventud Sin Futuro (Youth Without a Future), No Les Votes (Don't Vote For Them), Anonymous, ATTAC, and others, was coordinated and led. Put differently, the $15 \mathrm{M}$ field was a DRY-led coalition of citizen initiatives, with DRY successfully positioning itself as primus inter pares, a first among equals.

This was a truly civic field of action and media practice in that noncivic entities such as trade unions or political parties were barred from entry. This significant exclusion could be explained partly as a legacy from the country's strong autonomous movement tradition (Flesher Fominaya, 2014) and partly as a rejection of Spain's «transition culture», as defined above. At any rate, members of such organisations were welcome to participate, but only on a personal capacity, as individual citizens. A firsthand experience from my 2010-2011 fieldwork in Barcelona will illustrate this point about field exclusions. As the preparations for the 15 May demonstrations gathered pace, I joined an ad-hoc group of DRY volunteers who were compiling an online directory of citizens' groups likely to support the event. In keeping with the free-culture ideals of this civic initiative, we were using the collaborative site Pirate Pad, a free-software tool developed by Sweden's Pirate Party. When I pasted onto the pad the name and URL of a local political party from my own directory - published on my research blog - one of the informal leaders pointed out that only citizen groups were to be listed, not trade unions or political parties. I quickly erased this entry, which ironically linked to Catalonia's Pirate Party (Postill, 2012).

«Freedom technologists» - those geeks, hackers, technology lawyers, online journalists and other tech-minded citizens who use digital media to pursue democratic freedoms (Postill, 2014a) - made a fundamental contribution to the $15 \mathrm{M}$ field of civic action. For a start, the leading partner in the $15 \mathrm{M}$ coalition, DRY, was strongly rooted in the free culture scenes of Madrid and Barcelona. Free culture activists (see above) played key roles in the conceptualisation, organisation and dissemination of the new game from their Barcelona home base, as did their counterparts in Madrid and other cities. Other strong free culture partners included No Les Votes («Don't Vote for Them», derived from earlier digital rights mobilisations) and Anonymous. These technology specialists also trained less tech-minded 
citizens - many of them new to activism - in the use of both proprietary and free software tools for activism through workshops and other means.

\section{THE 17M FIELD OF CIVIC ACTION: «YES WE CAMP!»}

On the night of 15 May, practically all demonstrators followed the DRY script and went home, myself included (Postill, 2014b). Yet as retold by the free software activist Dani Vázquez, some forty demonstrators decided to stay on at Puerta del Sol, a large square in the heart of Madrid. The sit-in started slowly but on 17 May, after the shock of being evicted by the police, Sol was suddenly transformed into both a mass occupation and a global media event. So it makes field-theoretical sense to call this new game not $« 15 \mathrm{M} »$ but rather $« 17 \mathrm{M} »$.

From its very inception, the aim of the game was not to march the streets but to «occupy the square» (jToma la Plaza!). This is wittily encapsulated in the slogan: "Yes we camp!». The young independent journalist Juanlu Sánchez witnessed the following scene:

Another special moment, now forever etched in my mind, was when people started laying cardboard across Puerta del Sol square to spend the night there. Then came the blue tarpaulins, the formation of commissions, the fire brigade lending a hand - in a word, the building of the Medina! But it was the cardboard lain across the floor that truly defined that moment for me.The cardboard meant that people, a lot of people, were staying. ${ }^{1}$

In clear contrast to the now abandoned $15 \mathrm{M}$ game, the $17 \mathrm{M}$ game came without an expiry date, as explained by Dani Vázquez when recounting the first few hours of the encampment:

The idea was to agree amongst ourselves whether we should stay or go, as people were saying all sorts of things like "Let's stay till the elections», «Let's stay for good», «Let's stay until we win», «Let's stay a year if we have to». So it was more a case of saying: "OK, we're not going to agree on how long we're staying, but do we agree that we're staying? Yes? Well that's what we're going to say. We're staying put until we reach an agreement». ${ }^{2}$

The encampments soon became «cities within cities» whose internal governance units were commissions, working groups and assemblies. It was here that the field's core transient practices and stations were located during the month-long occupations. Although DRY and the other 15M

1 Source: Postill (2014a)

2 Source: Postill (2014a) 
players continued to exist, they were always peripheral to the new incumbents born in Sol and other squares across Spain. The commissions were charged with the everyday running of the camps, concentrating on cooking and cleaning, civil disobedience actions, artistic productions and communication. Meanwhile the working groups busied themselves with thematic issues such as the environment, the economy, and politics. There were also assemblies for campers as well as general assemblies that brought together campers and non-campers (Perugorría and Tejerina, 2013: 428, Postill, 2014b).

The media landscape, too, was transformed beyond recognition. Although the $15 \mathrm{M}$ marches became a global trending topic on Twitter they attracted scant attention from TV networks and other mainstream media (Postill, 2014b). By contrast, 17M was a phenomenal success both in its mainstream and social media output. This boom included «web forums, blogs, collaborative documents, pedagogical materials (e.g. on Spain's electoral system), analogic versions of digital forms (e.g. post-it tweets displayed publicly), print and online cartoons, citizen photography, radio phone-ins, live streaming from mobile phones, videoclips, and a huge range of social media texts, visual and audiovisual materials». Unlike their $15 \mathrm{M}$ predecessors, $17 \mathrm{M}$ players exploited to great effect Spain's hybrid media regions, with a virtuous circle of mainstream and alternative viral «sharing» of protest-related digital contents co-shaping the news cycle - an exemplary case of «viral reality» (Postill, 2014b). If 15M was all about civic media practices, $17 \mathrm{M}$ excelled at both civic and hybrid media practices (for a Tunisian parallel, see Lim, 2013).

Once again, freedom technologists played a crucial role in this field game, albeit under radically altered circumstances. These political actors were very well represented among the first forty occupiers of Puerta del Sol.They included the aforementioned free software specialist and activist Dani Vázquez who created the camp's highly influential Twitter handle (@ acampadasol) and main portal (Take The Square), as well as a prominent copyleft lawyer, a member of Anonymous who had previously broken into the Goya awards ceremony, and the hacktivist group Isaac Hacksimov for whom the occupation was «a gesture that broke the collective mental block» (Sánchez, 2011). Crucially, political actors working right across the media landscape were also highly active - something which did not happen during the $15 \mathrm{M}$ marches. These tech-savvy actors worked across fields such as journalism, documentary film-making, law, academia and entertainment, creating multiple bridges between the campers and other publics in 
Spain and abroad. In addition, freedom technologists worked at the top of the field's hierarchy of practices, for example, through digital practices that «mapped» the new movement's conceptual genealogy (Perugorría and Tejerina, 2013: 429).

\section{REVERTING TO DISPERSED CIVIC SPACE}

One of the more intriguing questions arising from a field-theoretical retelling of the indignados story is what to make of the long interval that took place between the end of the square occupations in mid-June 2011 and the irruption of new "citizen parties» onto the public scene in early 2014, in preparation for the European elections of May 2014. How do we account for these two-and-a-half years given that they can hardly be conceptualised as «a field of civic action»? And what is its political significance?

After the square occupiers vacated the squares following arduous deliberations on the matter, the movement devolved to myriad physical and online sites. This was a period of great experimentation with old and new initiatives or civic "prototypes» (Estalella \& Corsín Jiménez, 2013; Postill 2014a), some of which attained a great deal of media visibility and popular support, notably the anti-eviction platform PAH (Romanos, 2014), the crowd funded law suit against a corrupt banker 15MPaRato (led by former DRY participants) and the various «citizen tides» (mareas ciudadanas) that challenged Spain's ruling Popular Party's «austerocracy».

These various initiatives marked a «monitory citizenship» phase in the movement, that is, a mode of governance whereby public figures and institutions are subject to increased levels of scrutiny by the citizens, a trend fuelled by the explosive growth of social and mobile media in recent times (see Deuze, 2001; Keane, 2009). For example, Feenstra and Keane (2014: 1273) argue that PAH «successfully scrutinised and denounced Spanish mortgage laws, the banking system and the lack of response by elected representatives». Nevertheless, during this phase there was no shared game among the countless civic initiatives, no internal governance units, no central stations or dramatic arenas. That is to say, there was no field of civic action. According to Fligstein and McAdam (2011: 12):

[Strategic action fields] are stable when they have role structures that are based on either hierarchical incumbent/challenger structures or political coalitions. Unorganized social space, on the contrary, is characterized by the frequent entry and exit of organizations, 
no stable social relationships, and no agreement on means and ends. This kind of drift or conflict can go on for long periods of time.

To coin a more specific variant of this idea, I would suggest that dispersed civic space is a phase in the life course of a social movement in which a wide range of civic agents and agencies, including freedom technologists, experiment with new civic prototypes (and their constituent practices, actions and technologies), yet without coalescing into a web of socio-technical relationships, i.e. into a shared field of civic action built around a common issue (or small set of issues). This can be a period of confusion and disorientation, but it can also yield techno-political innovations and provide a training ground for new political actors who may go on to play active roles in a future field of civic action.

At this juncture we may wonder why this protracted period of dispersed space occurred in the first place and why the $15 \mathrm{M}$ movement did not die out.The answer to the first question is relatively straightforward: as we have seen, fields of civic action are necessarily time- and energy-intensive. After devoting themselves to two fields in rapid succession, most participants were exhausted, particularly following the month-long square occupations. The second question is more difficult and would require a separate discussion in its own right. Among the various factors that could account for the movement's survival it is reasonable to include the continued economic crisis - particularly the extremely high levels of unemployment - the harsh «austerity» policies pursued by the ruling Popular Party, as well as the remarkable resilience of leading activists from monitory initiatives such as PAH, 15MPaRato or the citizen tides. It is also worth bearing in mind that the movement always retained very high approval rates among the Spanish population, as regularly reported by some of the mainstream media.

\section{THE 25M FIELD OF CIVIC ACTION: «YES WE CAN!»}

In early 2014 a number of new political parties in Spain announced their intention to campaign in the European elections of 25 May 2014. The pioneer was Partido $\mathrm{X}$, a «citizen network» (red ciudadana) created in early 2013 by the same Barcelona freedom technologists behind DRY and 15MPaRato. Partido $\mathrm{X}$ is no ordinary party, for it draws on hacker/free culture principles and practices and regards itself as a «methodology» for po- 
litical change that be freely borrowed and remixed by other parties - so long as the borrowing is publicly acknowledged.

Indeed, soon after the new political party Podemos («We Can») was founded in early 2014, its leaders announced that they would borrow some of Partido X's techno-political methods (Público 2014). Podemos was one the biggest surprises in the European elections, obtaining 8 per cent of the vote in Spain and five seats in the European Parliament. Podemos is a leftist formation rooted in the indignados (15M) movement and led by the young, charismatic political scientist Pablo Iglesias.

How can we conceptualise in field-theoretical terms the irruption of Podemos, Partido X, and other new civic parties onto the electoral scene in early 2014? First of all, we find an interesting contrast with regard to the $15 \mathrm{M}$ and $17 \mathrm{M}$ "games». Because the 2014 initiatives joined non-citizen parties like Partido Popular (PP) or PSOE in this contest, thereby entering a shared field of civic and non-civic action, it is more appropriate to speak of a subfield of civic action in which Podemos, Partido $\mathrm{X}$ and other citizen parties were the challengers and parties like PP or PSOE were the incumbents of a neighbouring subfield.

What part did freedom technologists, as defined earlier, play in this new subfield of civic action? Podemos carried out a successful hybrid media (or transmedia) strategy right across the establishment vs. civic media divide by banking on its telegenic leader, Pablo Iglesias. In contrast, Partido $\mathrm{X}$ relied heavily on social media and opted for not playing the charismatic leader "game», paying for it at the ballot box, for they did not win any European seats. The main stations routinely used by Podemos included both alternative and mainstream TV studios, with Iglesias becoming a masterful practitioner of Spain's tertulia genre. Tertulias are popular TV and radio panel shows devoted to discussing current affairs. These media sites would often become arenas in which Iglesias and his more conservative opponents (many seasoned TV personalities) had no choice but to state baldly their position on a given issue, with Iglesias often emerging victorious.

This privileged position at the heart of the hybrid media system allowed Podemos to shape the system's viral reality propensities through the massive sharing and commenting of Iglesias' memorable TV moments via social media - and their subsequent recirculation by mainstream media organisations. By February 2017 Podemos was polling second nationwide after the conservative Partido Popular (PP). ${ }^{3}$

3 See http://cadenaser.com/ser/2017/02/07/politica/1486452180_447156.html 


\section{THE 24M FIELD OF CIVIC ACTION: «LET'S WIN!»}

Like the $15 \mathrm{M}$ marches (but not the open-ended square occupations), the $25 \mathrm{M}$ field came with a clear expiry date: 25 May 2014. Almost a year later to the day, a new perishable field formed around the 24 May 2015 local elections held across Spain. We could call it «the $24 \mathrm{M}$ field of civic action». In Barcelona, Madrid, Valencia and other major cities, new anti-establishment candidates either won or came very close to winning, signalling a major change in the country's political landscape.

For instance, Barcelona en Comú («Barcelona in Common»), formerly Guanyem Barcelona («Let's Win Back Barcelona»), also derived from a nonpolitical platform (the anti-eviction platform $\mathrm{PAH}$ ), emerged triumphant. Its charismatic leader, the former PAH leader Ada Colau, deployed, like Pablo Iglesias, a low-budget but highly effective transmedia strategy. Their electoral programme was drafted by over 5000 people, «with contributions made in open assemblies and online» (Baird, 2015). The new platform also gave birth to SomComuns, a network of internet activists campaigning on social media, as well as a collective made up designers and artists named The Movement for The Graphic Liberation of Barcelona.

SomComuns participants were free to experiment with language and media formats. As one of its initiators put it, «If a message works, we promote it, regardless of who created it. In fact, some of our top virals were made by anonymous people». An example of this «new electoral narrative» is the video El run run (The buzz), featuring a joyful Ada Colau. Not only did $E l$ run run strike a chord with campaigners, it also found its way into the mainstream media (Sandiumenge, 2015). This digital media savvy, however, only tells us half the story of Colau's success. The other half is her reputation as an 'antipolitical' grassroots activist fighting for ordinary people facing the repossession of their homes (Tormey, 2015: 115).

For Delclós (2015), the success of Barcelona en Comú and similar platforms marks the rise of a «new municipal agenda» in Spain. This agenda echoes the ideas of the founding father of libertarian municipalism, Murray Bookchin, who identified its four main features: «a revival of the citizens assembly, the need for confederation with other municipalities, grassroots politics as a school of genuine citizenship and the municipalisation of the economy«. Underlying this programme, argues Delclós, is «a recovery of a new participatory politics structured around free, self-empowered and active citizens». 


\section{DISCUSSION}

Reviewing the available evidence, it is clear that the $15 \mathrm{M}$ movement and its political offshoots - have created a new language and praxis of citizenship in Spain. The first stage in this process overlaps with the 15M (street marches) and 17M (square occupations) fields of civic action analysed earlier. This stage started via the offline and online generation of countless slogans by activists and ordinary citizens, widely "shared» via social media prior to the 15 May demonstrations (Postill, 2014b). The double slogan «Real democracy now! We are not commodities in the hands of politicians and bankers» became the «official» statement of the marches and remained highly visible during the square phase.This slogan resonated with many citizens in a country mired in a deep "crisis of legitimacy» as a result of the "corruption, cronyism and clientelism exercised by the two main political parties» (Tormey, 2015: 109). Although this is a negative formulation of collective identity, for it tells us what the protesters are not rather than who (or what) they are, the shared understanding was that the "we» referred to ordinary citizens/people - as we saw in the exclusion of political parties and trade unions from the original list of invited participants in the marches. The long weeks of assemblary and group work undertaken in the squares allowed protesters to reinforce the idea of a movement of citizens, of unique persons who represented no one but themselves (Perugorría and Tejerina, 2013).

The second stage of this language and praxis shift coincides with the movement's relatively dispersed phase of monitory citizenship following the dismantling of the tent cities in mid-June 2011.This was a linguistically less innovative phase, although it still produced imaginative formulations such as the idea and praxis of «citizen tides» (mareas ciudadanas) or the introduction by the anti-eviction platform PAH of the Argentinian tactic of escraches whereby citizens unable to pay their mortgages gathered loudly in front of politicians' homes to pressurise them into resolving this issue (Artistic Activism, 2013).Through these and other widely reported actions, PAH succeeded in transforming the «victims» of the mortgage fiasco into citizen-activists fighting for their social rights. Similarly, the monitory platform 15MPaRato activated thousands of ordinary citizens against a corrupt banker through novel digital means such as crowdsourcing and crowdfunding under the slogan «Only the citizenry can stop them» (Solo la ciudadanía puede pararlos), an effort amplified by sympathetic sectors of the mainstream media. 
Finally, the current stage of the movement, dominated by new citizen parties such as Podemos («We Can») and Barcelona en Comú, has seen the introduction of a carefully crafted set of new and old political terms around the themes of social justice, corruption and empowerment, with the country's derided establishment now referred to as «the caste» (la casta) and its citizens variously invoked as «the citizenry» (la ciudadanía), «the people» (el pueblo), «people» (la gente), and suchlike. Another notable feature of these new parties is their recycling of the $15 \mathrm{M}$ assemblary model through local «circles» or assemblies open to any citizen - a strategy that has fanned the parties' rapid growth but also exposed them to infiltration by opportunists with differing agendas.

\section{CONCLUSION}

I have argued that field theory can provide us the keys to unlock the elusive relationship between media change and the new citizen movements in Spain, and indeed elsewhere. To this end, two overlapping totalities must be understood holistically: (1) the total ephemeral fields formed by civic actors at specific conjunctures in the historical course of their countries, and (2) the hybrid media systems that shape and are shaped by these and other fields of action, including the fields of establishment media, party politics and policing. The result of this two-pronged analytical strategy was a retelling of the $15 \mathrm{M} /$ indignados story from a field-theoretical angle.

Looking back today at the protest events of 2011 in Tunisia, Egypt, Spain, Malaysia or the United States, we may at first see unified processes, sequences of events that followed one another in rapid succession to form «emergent» protest movements that eventually peaked and then seemingly fizzled out. Yet seen through the lens of field theory a very different pattern appears. In the case of Spain's indignados (15M) movement, during the 2011-2015 period instead of a continuous flow of events we find four distinct (sub)fields of civic action (15M,17M, 25M, and 24M) interrupted by a long period of dispersed civic space. These fields can be regarded as games of a kind.They are not games like chess, football or online poker, but rather contests in which civic "players» with unique skills and trajectories enter into relationships with other players (both individual and collective) in pursuit of specific rewards or prizes. 
These diverse initiatives have doubtless reinvigorated Spain's civic and political system, helping to mobilise millions of people and imbuing them with sense of purpose and a clear set of antinomies («us» vs. «them», «the citizenry» vs. «the caste»). In diachronic terms, a shift from an initial rejection of institutional politics to a current will to power is clearly discernible - a shift from «Yes we camp» (a favourite chant with square occupiers) to "Yes we can» (Podemos' leitmotif). As a result, Spanish citizens are today more aware than ever of their social rights - the right to a home, to public health, to a free education, and so on. Moreover, many of them have learned to transform this awareness into civic and/or political action, with increased success rates at the ballot box. This stands in sharp contrast to the pre-15M situation of civic quietism described by Benedicto (2006, see above) and other students of Spain's post-Franco transition. It follows that Spain's crisis of citizenship is far more than an object of academic curiosity - it is now integral to the national conversation and to the political calculations of the ruling elites (and their opponents) as the country enters an uncertain period of democratic renewal.

Freedom technologists bring to the multiple field sites in which civic contention currently takes place in Spain - its streets, squares, TV studios, newsrooms, social media sites, political rallies, etc. - a unique experience and passion for exploring the limits and possibilities of mixing technology with politics, a capacity for civic experimentation, and a tendency to share its fruits through free-culture mechanisms. They also contribute a growing realisation (which came as a shock to many in late May 2014) that we live in hybrid media systems in which we dismiss «old» media such as radio or TV at our own peril.

\section{REFERENCES}

Artistic Activism (2013): "Escrache in Spain», 16 April 2013. Available at: http://artisticactivism.org/2013/04/escrache-in-spain/ (accessed 3 May 2017).

BAIRD, K.S. (2015): «Beyond Ada Colau: the common people of Barcelona en Comú», Open Democracy, 27 May 2015. Available at: https://www.opendemocracy.net/can-europe-make-it/kate-shea-baird/beyond-ada-colaucommon-people-of-barcelona-en-com\%C3\%BA (accessed 3 May 2017).

Boler, M. et. Al. (2014): «Connective labor and social media:Women's roles in the 'leaderless' Occupy movement», Convergence 20(4), pp. 438-460. 
Born, G. (2010): "The Social and the Aesthetic: For a Post-Bourdieuian Theory of Cultural Production", Cultural Sociology 4(2): pp. 1-38.

Bourdieu, P. (1990): In Other Words: Essays towards a Reflexive Sociology, Stanford, CA, Stanford University Press.

- (1993): The Field of Cultural Production, Cambridge, Polity Press.

- (1996): The Rules of Art: Genesis and Structure of the Literary Field, Cambridge, Polity Press.

Bourne, A. And Chatzopoulou, S. (2015): «Europeanization and Social movement mobilization during the European Sovereign Debt Crisis: the Cases of Spain and Greece», RECERCA, Revista de Pensament y Anàlisi, 17 (30), pp. 33-60.

Butler, J. (1999): «Performativity's Social Magic», in R. Shusterman (ed.), Bourdieu:A Critical Reader, Oxford, Blackwell, pp. 113-28.

Chadwick,A. (2013): The Hybrid Media system: Politics and Power, Oxford, Oxford University Press.

Costanza-Chock, S. (2012): «Mic check! Media cultures and the Occupy Movement», Social Movement Studies, 11(3-4), pp. 375-385.

Delclós, C. (2015): «Towards a new municipal agenda in Spain», Open Democracy, 26 May 2015. Available at: https://www.opendemocracy.net/ can-europe-make-it/carlos-delcl\%C3\%B3s/towards-new-municipal-agenda-in-spain (accessed 3 May 2017).

DekKer, P. AND Feenstra, R. A. (2015): «Activism and civil society: Broadening participation and deepening democracy», RECERCA, Revista de Pensament y Anàlisi, (17), 7-13.

Deuze, M. (2001): «Online journalism: Modelling the first generation of news media on the World Wide Web», First Monday, 6(10).

Estalella, A. And Corsín Jiménez,A. (2013): «Asambleas al aire: La arquitectura ambulatoria de una política en suspensión», Revista de Antropología Experimental 13, pp. 73-88.

Feenstra, R. A. And Keane, J. (2014): «Politics in Spain: A case of monitory democracy», VOLUNTAS, International Journal of Voluntary and Nonprofit Organizations, Online First, pp. 1-19.

Flesher Fominaya, C. (2014): «Debunking Spontaneity: Spain's 15-M/Indignados as Autonomous Movement», Social Movement Studies, 14(2), 142163.

Fligstein, N., AND MCAdAM, D. (2011): «Toward a general theory of strategic action fields», Sociological Theory, 29(1), 1-26.

- (2012): A Theory of Fields, Oxford, Oxford University Press. 
Gerbaudo, P. (2012): Tweets and the Streets: Social Media and Contemporary Activism, London: Pluto Press.

Gledhill, J. (2000): Power and its Disguises: Anthropological Perspectives on Politics, London: Pluto.

JURIS, J. S. (2008): Networking Futures: The Movements against Corporate Globalization, Durham, NC, Duke University Press.

Keane, J. (2009): The Life and Death of Democracy, London, Simon \& Schuster.

Kelty, C. (2008): Two Bits:The Cultural Significance of Free Software, Durham, NC, Duke University Press.

LIM, M. (2013): «Framing Bouazizi: 'White lies', hybrid network, and collective/connective action in the 2010-11 Tunisian uprising», Journalism, 14(7), pp. 921-941.

Papa, V. And D.L. Milioni (2013): «Active Citizenship or Activist Citizenship? A Framework for Studying Citizenship in New Social Movements and the Role of ICTs», Networking Knowledge:Journal of the MeCCSA-PGN, 6(3).

Perugorría, I., ANd B. Tejerina (2013): «Politics of the encounter: Cognition, emotions, and networks in the Spanish 15M», Current Sociology 61 (4), pp. 424-442.

Postill, J. (2002): «Clock and Calendar Time: A Missing Anthropological Problem», Time and Society 11, pp. 251-270.

- (2006): Media and Nation Building: How the Iban Became Malaysian, Oxford, UK, Berghahn.

- (2011): Localizing the Internet: An Antbropological Account, Oxford, UK, Berghahn.

- (2012): «Participatory media research and Spain's 15M movement», Cultural Anthropology, August 2012.

- (2014a): "Freedom technologists and the new protest movements: a theory of protest formulas», Convergence, 20(4), pp. 402-418.

- (2014b): «Democracy in an Age of Viral Reality:A Media Epidemiography of Spain's Indignados Movement», Etbnography, 15(1), pp. 50-68.

- (2015): «Fields: Dynamic configurations of practices, games, and socialities». In V. Amit (ed.) Thinking Through Sociality: An Antbropological Interrogation of Key Concepts, Oxford, Berghahn, pp. 47-68.

Prior, N. (2008): «Putting a Glitch in the Field: Bourdieu, Actor Network Theory and Contemporary Music», Cultural Sociology, 2 (3), pp. 301 319. 
Público (2014): «El Partido X cede su método de participación ciudadana a la iniciativa Podemos», 4 February 2014. Available at: www.publico.es/ politica/499800/el-partido-x-cede-su-metodo-de-participacion-ciudadana-a-la-iniciativa-podemos (accessed 3 May 2017).

Romanos, E. (2014): «Evictions, Petitions and Escraches: Contentious Housing in Austerity Spain», Social Movement Studies, 13(2), pp. 296-302.

SÁnCHEZ, J.L. (2011): «Los primeros 40 de Sol», Periodismo Humano, 26 May. Available at http://periodismohumano.com/temas-destacados/losprimeros-40-de-sol.html (accessed 3 May 2017).

SAndiumenge, L. (2015): «La guerrilla digital de Colau», Districte 15, 23 May 2015. Available at http://districte15.info/la-guerrilla-digital-de-colau/ (accessed 3 May 2017).

Silverstone, R. (1999): «What's new about new media?» New Media E Society, 1(1), pp. 10-12.

Tormey, S. (2015): «Democracy will never be the same again: 21 st Century Protest and the Transformation of Politics». RECERCA. Revista de Pensament y Anàlisi, (17), pp. 107-128.

Turner, V. (1974): Dramas, Fields and Metapbors: Symbolic Action in Human Society, Ithaca, NY, Cornell University Press.

Vv.AA. (2012): CT o la cultura de la transición: Crítica a 35 años de cultura española, Barcelona, Debolsillo.

WARDE,A. (2004): «Practice and field: revising Bourdieusian concepts», CRIC Discussion Paper 65, April 2004.

- (2005): «Consumption and theories of practice»,Journal of Consumer Culture 5, pp. 131-53. 